\title{
A Virtual Ethnography Study: Fandom and social impact in digital era
}

\author{
Ade Kusuma', Adiasri Putri Purbantina², Vina Nahdiyah³, Ucik Uswatun Khasanah ${ }^{4}$ \\ 1 Universitas Pembangunan Nasional (UPN) Veteran Jawa Timur, Indonesia. \\ Email: ade kusuma.ilkom@upnjatim.ac.id \\ 2 Waseda University, Japan. Email: adiasri-p@suou.waseda.jp \\ 3 Universitas Pembangunan Nasional (UPN) Veteran Jawa Timur, Indonesia. \\ Email:vinanahdiyah99@gmail.com \\ 4 Universitas Pembangunan Nasional (UPN) Veteran Jawa Timur. Indonesia. \\ Email:ucikuk123@gmail.com
}

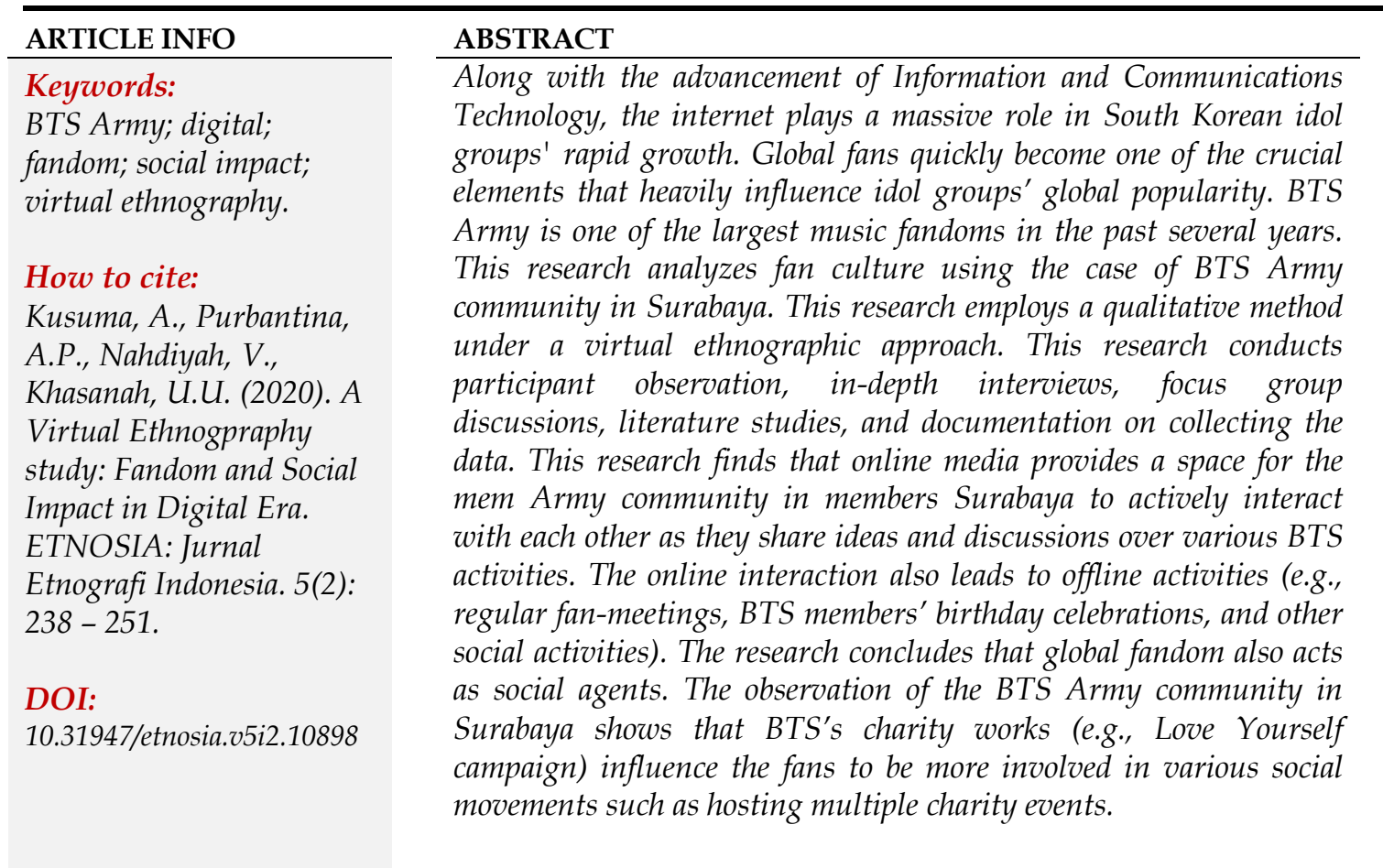

\section{Introduction}

Globalization, through the advancement of the Information and Communications Technology, has led to global cultural interconnectedness. It enables the exchange of information, way of thinking, and values. In this regard, several globalization scholars point out that globalization can lead to the threat of cultural hegemony. The threat of cultural hegemony due to globalization will open the entrance of various ideologies, 
lifestyles, and foreign cultures, especially through media channels, which have come to the attention of the theorists of globalization (Kumbara et al., 2020: 10).

However, globalization hugely benefited South Korean culture when the Hallyu 1.0 led to the rapid growth of South Korean culture globally, both traditional and popular. The Hallyu boom did not originate in the domain of traditional Korean high-culture, but of contemporary pop-culture, such as dance music, rhythm, and blues, funk, hip-hop songs of Korean idol groups (Bok-rae, 2015). The Korean Wave gained their popularity in Indonesia since the 2000s, through Korean Drama (K-Drama) such as Endless Love (Autumn in My Heart), Winter Sonata, My Sassy Girl, and Jewel in the Palace. In an article entitled An Analysis of the Korean Wave as Transnational Popular Culture, Dal Yong Jin argues that the social mediascape of the new Korean Wave is conditioned by cultural contexts in which they are situated, and which characterizes the Korean Wave as a unique brand of social-mediated popular cultural flows (Jin, 2018).

The Hallyu 2.0 era began in 2006 with the presence of K-pop Idols (K-stars-oriented), as did Girls' Generation, Kara, Shinee, 2PM, Big Bang (Bok-rae, 2015). Online media significantly influenced the spread of K-Pop idol groups' activities, especially Youtube and social media. Being analyzed by cultural studies point of view, K-pop phenomenon is not only understood as a hit phenomenon of pop music right now, but there is also political interest behind Korean music, namely the soft counter-culture strategy carried out by the Korean government, the people commodities in Korea, and in collaboration with commodities in Indonesia (Ardia, 2014).

Since early 2010, Hallyu has not been limited to K-dramas or K-pop music but included all genres of Korean culture (Bok-rae, 2015). The South Korean government started to assume active roles in promoting South Korean cultural exports (e.g., fashion, cosmetics, tourism). Several scholars noted this as Hallyu 3.0. era, where the South Korean government places South Korean culture (i.e., K-Culture) at the center of their development policy. The research article entitled "Past, Present and Future of Hallyu (Korean Wave)" argues that fans like and imitate the identity of Hallyu stars (Bok-rae, 2015). Bok-rae also explains the future Hallyu 4.0 era will come from South Korean fashion because Hallyu stars also become a fashion role model for their global fans. In this regard, Hallyu stars are influential when they become fashion brand ambassadors.

In Indonesia, K-Pop music has a large presence, followed by the emergence of various K-Pop fandoms. K-Pop becomes part of Indonesian popular culture. Popular culture fans consume a specific content, artist, and/or text of mass-produced popular cultural contents in their daily lives (Jang \& Song, 2017). Chang (2014) argues that we can perceive fans as cultural labor. In other words, fans produce cultural products and cultural capital (Chang, 2014). In Indonesia, K-Pop fans pay close attention to K-Pop music and their lifestyle and inspirational stories. Therefore, the appreciation of a foreign media text, so some extent, does not exclusively depend on the degree of the cultural values represented or the textual intimacy, but also on the attractiveness of the stars' appearance and the creation of characters (Ida, 2008). 
A fan is a person with a relatively deep, positive emotional conviction about someone or something famous, usually expressed through an recognition of style or creativity (Duffett, 2013). A fan supports their idols' activities, both individually and in a group (i.e., fandom). Abundant scholars already discuss the emergence of K-Pop fandoms and their activities. In Indonesia, the public often perceives fandoms in a negative light. They generally consider loyal fans' activities as wasteful (i.e., buying original albums and merchandise, using most of their internet quotas to watch concert performances, celebrating idols' birthday). On the other side, fans also participate in numerous social activities, which often do not receive enough public attention.

The internet fundamentally changed fandom (Booth, 2018). Today, fandoms communicate and interact primarily through online media in addition to a traditional offline meeting. The reach of fandom is not only limited to certain regions but can quickly develop globally. Fandom in convergent technology era is a group of global popular culture fans who are active and use social media to develop their participation and to build their group identity (Sugihartati, 2017).

We can observe this through the involvement of global fandoms in various music awards, such as the Billboard Music Awards. Through this award, we can observe how some of the largest fandoms successfully determined the winner. One of the best examples is how the BTS's global fandom (i.e., BTS Army) contributed to BTS's victory in the Top Social Artist award since 2017. They defeated Justin Bieber's global fandom (i.e., Beliebers), who has been the reigning champion for six years. Furthermore, BTS defended their titles in 2018 and 2019. The BTS Army themselves also received several awards for their global fandom activities.

A.R.M.Y is an abbreviation of Adorable Representative M.C for Youth. BTS-Army is the largest fandom in the world. The estimated number of it is 18 million people (Tokopedia, 2019). An article entitled 'The Strength Of K-Pop Fandom, By The Numbers' also explains that BTS-Army was one of K-Pop fans who wanted to spend a lot of money to advertise in Times Square (Blake, 2018). There are a large-numbers of BTS Army fandom in Indonesia. The development of the K-Pop music industry globally also has an impact in Indonesia. According to the AVP of Business of Tokopedia, Jessica Stephanie Jap, BTS members said to her that they had realized that the Army in Indonesia, as BTS fans, had been one of the biggest Army in Asia (Aditia, 2019).

This research is a fan study research focusing on media fans and fan cultures. Fans studies became a hall mark in the analysis of new media studies and digital culture (Lamerichs, 2018). Fan studies see that a fan actively and creatively participates in developing the social identity of a fandom. This study seeks to uncover social attitudes toward class, gender, and other dimensions of social identity. Fan studies aim to represent fandom in a positive light and tend to study fan communities and practices. Cavicchi, as cited on Duffett (2013) argues that fan refer to diverse individuals and groups, including fanatics, spectators, groupies, enthusiasts, celebrity stalkers, collectors, consumers, members of subcultures, and entire audiences, and depending 
on the context, to refer to complex relationship involving affinity, enthusiasm, identification, desire, obsession, possession, neurosis, hysteria, consumerism, political resistance, or a combination (Duffett, 2013).

Duffet (2013) states that when fans gather, then a fandom is formed. Fandom is a social cultural phenomenon largely associated with modern capitalist societies, electronic media, mass culture and public performance (Duffett, 2013). Global fandoms, through social media, bring together people who might not interact in real life. Fan studies look into fan communities to explain how fans actively develop their own social-cultural identity. This research focuses on how fandoms' cultural identity takes manifestation in the role of local fandoms as social agents that influence the popularity of their idol. Using the case of BTS-Army community in Surabaya, who has been active since 2013, this research explores how fandoms play a role in increasing idol groups' popularity in the digital age.

\section{Method}

This research is qualitative research, which examines social interactions (i.e., global fandom) in a virtual environment under a virtual ethnography approach. Ethnography is an approach for studying everyday life as lived by groups of people, provides powerful resources for the study of the cultures of virtual worlds (Boellstorff et al., 2003). Researchers conduct participant observation in the group to explore the group's way of life and way of thinking. In the digital age, ethnographic research does not only resonate with anthropology and sociology studies but also with communication science study. The space for interaction expands into cyberspace (i.e., computedmediated communication), where communities transform into virtual communities. Virtual communities are social aggregations that emerge from the Net when enough people carry on those public discussions long enough, With sufficient human feeling, to form webs of personal relationships in cyberspace (Hine, 2000).

Following Hine (2000), the virtual ethnography approach involves intensive engagement with mediated interaction. Technological advancement (i.e., new media), as the medium, becomes a crucial element. Hine argues that "ethnographer's engagement with the medium is a valuable source of insight" to embrace a "reflexive dimension" in data collection (Hine, 2000). To validate the data, Ida and Achmad (2018) argue that virtual ethnography can involve various additional offline methods to support participant observation, such as questionnaires and semi-structured interviews. Offline data collection is useful when discussing the issues of originality and correctness of data (Achmad \& Ida, 2018).

Therefore, this research's primary data collection consists of two stages: participant observation and focus group discussion. First, the researchers join the BTS-Army community in Surabaya as a temporary member. Here, the researchers become a part of the community's group chat in a cross-platform messaging app (i.e., the medium). The researcher interacts as part of the virtual fandom and involves in various virtual 
fandom activities. The ethnographic interviewing process referred to as "shared experienced" and this is what distinguishes it from other research interview practices because interviews in ethnography provide benefits in term of depth and wealth of results (Achmad \& Ida, 2019). The key here is the "shared experienced" as part of the community. The second stage starts with focus group discussions, followed by an indepth interview with selected key informants. The number of informants in a virtual ethnographic study is not determined in number, but it is adjusted to the research objectives and the analysis's interests (Achmad., 2019). In this research, the key informants were administrators of social media of the BTS-Army Surabaya Community. Besides, we also incorporate additional secondary data to support our interpretation of the primary data.

\section{Result and discussion}

To analyze the case of BTS-Army community in Surabaya, we first need to discuss their social, cultural identity of the BTS-Army community in Surabaya. In the second subsection, we focus on how this identity takes manifestations in their activities. In the final subsection, we discuss how the fandom becomes social agents that supports idol's popularity.

\section{- Cultural Identity of BTS-Army Surabaya Community}

Fan culture is made by a new type of cultural community, where affiliation is voluntary and based on common pattern of consumption, common ways of reading and relating to popular text, yet, one serving many of the traditional function of folk culture (Jenkins, 1992). Cultural identity refers to the characteristics of a cultural group. A cultural identity manifests among the members of the cultural community. According to Klyukanov, cultural identity can also be seen as membership in a group where everyone uses the same symbol system (Samovar et al., 2010).

Army is a fan name or fanbase name of BTS (Bangtan Sonyeondan). BTS is a sevenmember K-Pop idol group, who debuted in 2013. The seven members are RM (real name Kim Namjoon), Jin (Kin Seokjin), Suga (Min Yoongi), J-Hope (Jung Hoseok), Jimin (Park Jimin), V (Kim Taehyung), and Jungkook (Joen Jungkook). As an idol group, their activities range from singing, rapping, dancing, and acting. In English, the name BTS (i.e., Bangtan Sonyeondan) means the bulletproof boy scouts. BTS's original meaning gave birth to another interpretation for BTS-Army as a shield or protector for BTS. The BTS-Army has its purple color symbol, the BTS's concert lightstick color (i.e., the Army Bomb).

The BTS-Army community in Surabaya emerged in 2013. In 2020, it consists of 150 to 200 members. Since its inception, the BTS-Army community in Surabaya went through three times of management restructuring. The members come from various ages, genders, or social statuses, who joined the community for their similarity of interests. As K-Pop's influence grows deeper into Indonesian society, the BTS-Army community 
member in Surabaya also points out how BTS's works integrate with their daily lives. They spend their days listening to BTS music and watching BTS videos online.

We use the online media (e.g WhatsApp, Instagram, and Twitter) to communicate all the good things about BTS and remind each other to vote at the awards event. Trying to establish connections with the BTS-Army throughout Surabaya to Indonesia. Sometimes also with international BTS-Army [DF, interview on March 8, 2020].
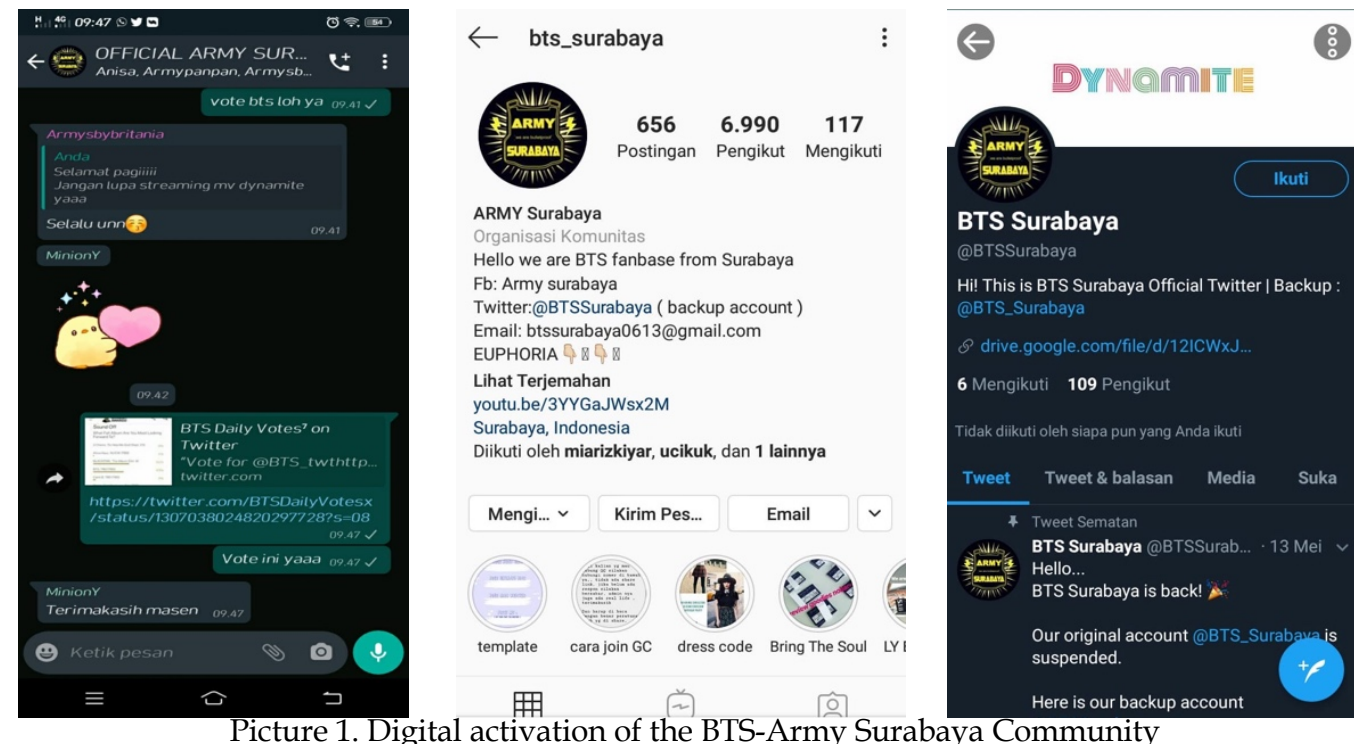

(source: capture WhatsApp conversations, Instagram and Twitter account of the BTS-Army Surabaya Community)

Online media brings the fans closer to their idol despite being geographically live far from each other. As a new medium, online media enables faster and easier access to information and social interactions. They have the luxury now of increased access to information, a greater speed of social interaction, and a new means of public performance (Duffett, 2013). Big Hit Entertainment, as the management company of BTS, takes advantage of online media. They provide various online media platforms to promote BTS activities, such as Youtube, Twitter, Instagram, Vlive, and Weverse. The BTS channel youtube account is Big Hit Labels. All video shows on the account are official movie videos launched by Big Hit Entertainment. BTS members do not have personal accounts on all types of social media. However, they update the fans through official Twitter accounts of BTS are @BTS_twt, and Instagram @bts.bighitofficial. They often post personal or group activities as a form of linear communication with fans. 


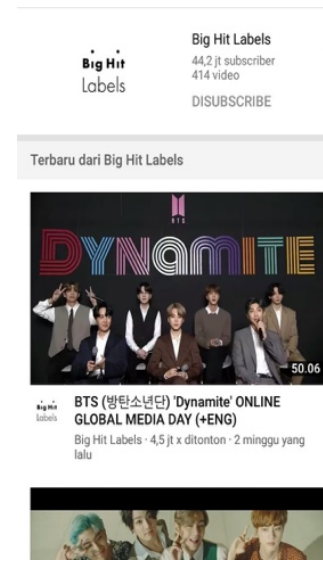

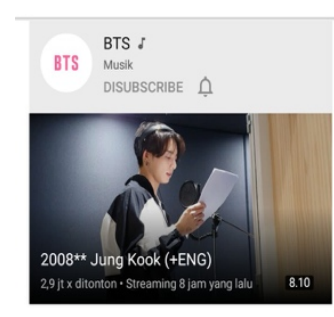

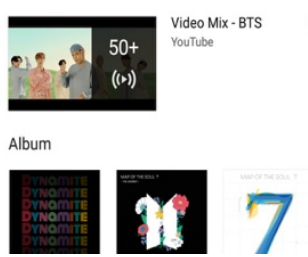

Picture 2. Online Media Platforms of BTS

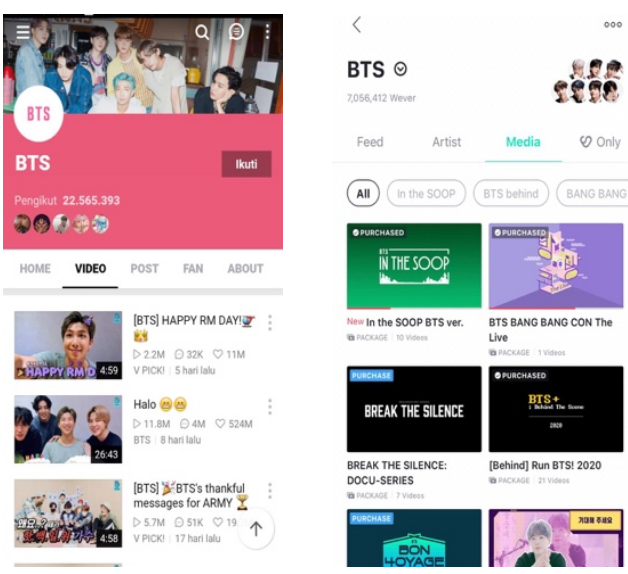

ToN

(Source: The Youtube channel of Big Hit Labels and Bangtan TV, BTS Vlive account, BTS Weverse account)

Vlive and Weverse function differently in comparison to Twitter or Instagram. Vlive is a live broadcasting app used by K-Pop idol groups from different entertainment houses, mostly to hold online interaction with the fans (i.e., fans can leave comments or reactions directly while an idol group turns on a live broadcast). While Vlive's target is the general public, Weverse is a global fan community platform launched by beNX, a Big Hit Entertainment subsidiary. In this regard, Weverse acts as a fan-exclusive platform, where the BTS members also interact with the fans through comment sections.

Big Hit consistently maintains the idol's relationship with BTS-Army through its content on YouTube or social media. Even though sometimes we get overwhelmed to watch. The impact, now I am learning Korean at Rumah Bahasa [NP, interview on March 8, 2020].

While both Vlive and Weverse provide English, and sometimes Indonesian subtitles, mostly the BTS member writes and communicates with fans in the Korean language. The BTS-Army community administrator in Surabaya stated that the language barrier is one of the obstacles that they seek to tackle to feel closer to BTS members. The language barriers become the BTS-Army motivation to study the Korean language by themselves (i.e., self-thought).

Chang presents thoughts about K-pop music, which is a cross-cultural media product, so fans must face two identities (Chang, 2014). The fans, or fan groups, struggle to face cultural conflict as they construct their self-identity. Lee (1998) suggests that the audience of the receiving country does not adopt and respond to the foreign program contents in one single way. Without this learning and adopting process, there is no way to form a "global culture" through sameness (Ida, 2008). The members of the BTSArmy community in Surabaya adopt the Korean culture (e.g., Korean language and expressions, Korean gestures, Korean lifestyles). 


\section{- Online Fandom Activities of BTS-Army Community in Surabaya}

Fandom here becomes a participatory culture which transforms the experience of media consumption into the production of new texts, indeed of a new culture and a new community (Jenkins, 1992). Fans do not only remix texts to create new meanings, but they also archive these texts themselves on their own communities. (Lamerichs, 2018).

The BTS-Army community in Surabaya utilizes online media for their fandom activities, such as fan-project, charity events, and other members' social communication. They use WhatsApp and Line as messaging applications among them. While for social media, they have Facebook, Instagram, and Twitter. BTS-Army community in Surabaya has its social media accounts @BTS_Surabaya (Twitter), and @bts_surabaya (Instagram) is open and can be followed by anyone who has the same interests. BTS itself is one of the most active idols on Twitter, so it demands the BTSArmy also actively uses the application. @BTS_Surabaya often posts or retweets good news about BTS from various sources of information. Meanwhile, the Instagram account @bts_surabaya shows more details of various activities carried out by the Surabaya BTS Army community.

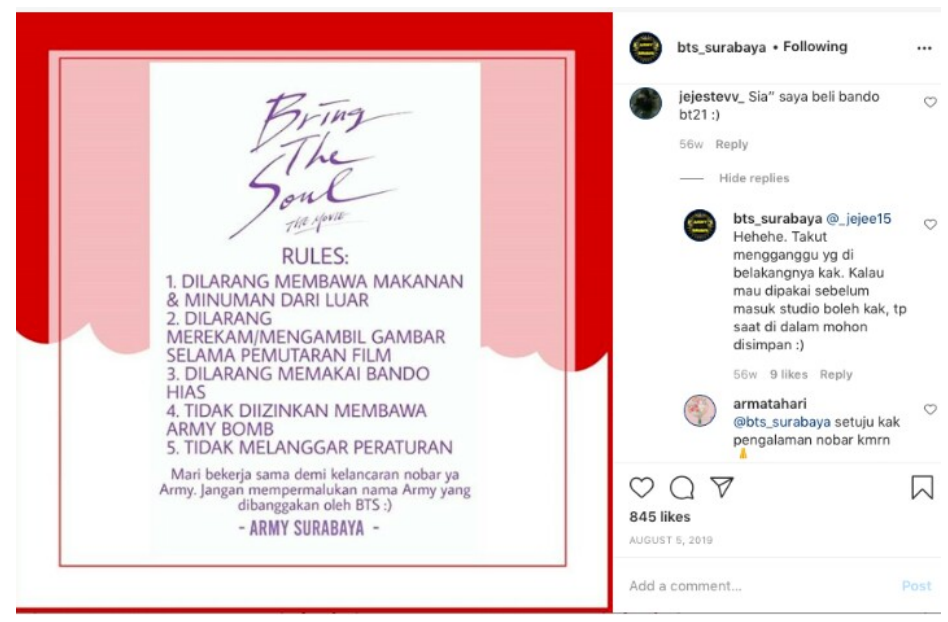

Picture 3. The rules of event watching together a documentary film of BTS "Bring The Soul" in cinema (posted in Instagram feed of @bts_surabaya on August 5, 2019)

On August 7, 2019, the BTS-Army community in Surabaya coordinated "a watching together" event with a BTS documentary film entitled 'Bring The Soul' in cinema. The event was held at CGV BG-Junction Surabaya $6.30 \mathrm{pm}$ in three different studios, with 457 participants. The committee informed that ticket purchases were made via the @bts_surabaya Instagram account since July 2, 2019, while ticket booking services were made via chat on Line or WhatsApp. They documented and shared the whole preparation process, including spread the information, on the Instagram account page @bts_surabaya. 
Once we organized the event, watch a Bring the Stage movie together at the cinema. But we became like watchdogs so that the audience would be orderly, especially to ensure that no one would record in the cinema. It is strictly forbidden. Don't make a bad image of the name BTS-Army [SAND, interview on March 8, 2020].

The committee used their social media accounts to inform the BTS-Army on various rules. They encouraged BTS-Army to comply with the theater's rules, such as the prohibition of bringing food and drinks from outside, prohibited from a recording or taking pictures during film screenings, prohibited from wearing decorative headbands, the BTS-Army are not permitted to carry army bombs, and violates other rules. The administrator uses persuasive words. They encouraged the BTS-Army to maintain BTS fandom's positive image, specifically the BTS-Army community in Surabaya. The BTSArmy community on Surabaya held the "watching together" event as one of many offline fan gatherings. They seek to strengthen the bond between the member though various offline events.

"Mari bekerja sama demi kelancaran nobar ya Army. Jangan mempermalukan nama Army yang dibanggakan oleh BTS :) - ARMY SURABAYA" (posted in Instagram feed of @bts_surabaya on August 5, 2019)

The community's social media accounts function as a close group. It provides closed chat rooms exclusively for the member of the BTS-Army community in Surabaya. Within this community, often the members never meet in real life, yet they are under the same system following the same values. In Surabaya, the BTS-Army community establish their own sets of rules, such as members are prohibited from sharing paid content, conducting sales promotions in any form, discussing other idols besides BTS, and triggering fan war. The chat rooms also act as a medium to promote BTS activities, particularly during awards season, when fandom votes become crucial for the idol groups to win. Overall, online fandom activities become the manifestation of their cultural identity, influenced by the idols' value. In the next section, we will focus on how the BTS-Army community in Surabaya acts as a social agent who extends BTS's positive message (i.e., The Love Yourself campaign) at the local level. This is how we present our arguments on the local fandom's role to influence the idol group's popularity.

\section{- BTS-Army Community in Surabaya as Social Agents for Love Myself Campaign}

As cited by Hills (2002), Cavicchi argues that fans are, in one sense, 'ideal consumers'. Since their consumption habits can be very highly predicted by the culture industry, and are likely to remain stable. But fans also express anti-commercial beliefs, or ideologies (Hills, 2002). Our findings show that the BTS-Army Community in Surabaya acknowledges the typical costly fandoms' activities. However, they refuse the perception of fandoms' activities as wasteful. They argue that the regular fan gatherings allow them to get to know each other to share life experiences.

Concerning the fandom as a community, BTS's Love Myself campaign with UNICEF plays an essential part in this case. Coincides with their Love Yourself album series, 
BTS and UNICEF launched the Love Myself campaign is an anti-violence campaign in 2017. They raised over US\$ 2 million to help UNICEF \#ENDviolence in and around schools (Wylie, 2019). In addition to the campaign, BTS members also actively participate in various charity and donations, both widely reported or not by the media.

Since their debut in 2013, BTS' music continues to be consistent with their message about social awareness (Table 1). The theme of their albums addresses various issues faced by the young generations. They talk about the problem of the educational system, mental health, lifestyle, consumerism. Through the Love Yourself series, they promote their way of achieving happiness and dreams. It is crucial to notice that the members write their lyrics.

Table 1. BTS Discography (Big Hit Entertaiment, 2020)

\begin{tabular}{|c|c|c|}
\hline Album & $\begin{array}{l}\text { Years of } \\
\text { Release }\end{array}$ & The Masseges \\
\hline 2 Cool 4 Skool (The 1st Single Album) & 2013 & What is your dream? \\
\hline O!RUL8, 2? (The 1st Mini Album) & 2013 & $\begin{array}{l}\text { You must find your happiness and your own life } \\
\text { before it's too late }\end{array}$ \\
\hline Skool Luv Affair (The 2nd Mini Album) & 2014 & $\begin{array}{l}\text { The love that blossoms in the school (dreams, } \\
\text { happiness, and love of teens) }\end{array}$ \\
\hline Dark \& Wild (1st Full-Length Album) & 2014 & Love gone awry in dark and wild \\
\hline $\begin{array}{l}\text { The Most Beautiful Moment in Life Pt.1 } \\
\text { (The 3rd Mini Album) }\end{array}$ & 2015 & $\begin{array}{l}\text { The uncertain future more than the glamour of } \\
\text { youth }\end{array}$ \\
\hline $\begin{array}{l}\text { The Most Beatiful Moment in Life Pt. } 2 \\
\text { (The 4rd Mini Album) }\end{array}$ & 2015 & $\begin{array}{l}\text { The energy of youth barreling forward, } \\
\text { embracing even the uncertainty and insecurity }\end{array}$ \\
\hline $\begin{array}{l}\text { The Most Beautiful Moment in Life : } \\
\text { Young Forever (1st Special Album) }\end{array}$ & 2016 & $\begin{array}{l}\text { The last stories told by young people who, } \\
\text { despite an uncertain and insecure reality } \\
\text { continue to surge forward }\end{array}$ \\
\hline Wings (2nd Full-Length Album) & 2016 & $\begin{array}{l}\text { Boys who encounter temptation for the first time } \\
\text { and must ponder and agonize in the face of it }\end{array}$ \\
\hline $\begin{array}{l}\text { You Never Walk Alone (2nd Special } \\
\text { Album) }\end{array}$ & 2017 & $\begin{array}{l}\text { We can laugh if we are together, a message of } \\
\text { comfort and hope to the youth of this generation }\end{array}$ \\
\hline $\begin{array}{l}\text { Love Yourself "Her" (The 5th Mini } \\
\text { Album) }\end{array}$ & 2017 & Loving yourself is the beginning of true love \\
\hline $\begin{array}{l}\text { Love Yourself "Tear" (3rd Full-Length } \\
\text { Album) }\end{array}$ & 2018 & $\begin{array}{l}\text { Fake love inevitably leads to loss and separation. } \\
\text { For true love can only begin when you learn to } \\
\text { love yourself }\end{array}$ \\
\hline $\begin{array}{l}\text { Love Yourself "Answer" (Repackage } \\
\text { Album) }\end{array}$ & 2018 & Loving oneself is where true love begins \\
\hline $\begin{array}{l}\text { Map of The Soul : Persona (The 6th Mini } \\
\text { Album) }\end{array}$ & 2019 & $\begin{array}{l}\text { The joy in finding love, and reaches out to the } \\
\text { world }\end{array}$ \\
\hline $\begin{array}{l}\text { Map of The Soul : } 7 \text { (4th Full-Length } \\
\text { Album) }\end{array}$ & 2020 & $\begin{array}{l}\text { The honest and hearthfelt story of BTS and their } \\
\text { journey of discovering their true selves }\end{array}$ \\
\hline
\end{tabular}

The music influences the fans, their identity, and how they assume their social roles. The members of the BTS-Army community in Surabaya state that they always listen to BTS music in their daily life. They argue that the songs calm them and provide them 
with mood booster when they are struggling with study or works. The members list some of the songs: Fire, Not Today, Idol, Persona, which are vital to them. Other influential songs are Epiphany, No, and So Far Away. They state that Epiphany teaches them self-love. Meanwhile, No and So Far Away make them realize their worth instead of being caught up in other people's dreams. The member states that the two songs provoke them to decide as they learn to be a responsible young adult.

BTS music and songs have inspired since I was in school (2014). Some so touching, like Magic Shop. The others are also for entertaining [DF, interview on March 8, 2020].

Don't live in another's dream... it is one of the part in the lyrics of BTS Song 'NO' that reminds me that how is unhappy me. I only do what my parents ask, go to school, study and repeat every day. I do not have idea what should I do in the future. In the song lyric of 'So Far Away', it is reminded me again, too sad if you do not have something, like your own passion and dream. [MRR, interview on March 8, 2020].

We argue here that fans are active audiences. They are agents who construct their interpretation over their idol groups' behavior. Despite BTS mostly delivering their messages in the Korean language (i.e., their songs, their campaigns, etc.), the BTSArmy community in Surabaya argues that the messages transcend the language barrier. It enables the fans to find a connection to their daily life struggles.

There was once a member of the Surabaya BTS Army who felt depressed because of a broken home family. She often hurt herself. We listened and supported her personally, also reminded her of what campaigned for Love Yourself in their songs [SAND, interview on March 8, 2020].

In Collective Intelligence, Pierre Levy, as cited by Jefkins (2006) offers a compelling vision of the new "knowledge space," or what he calls "the cosmopedia," that might emerge as citizens more fully realize the potential of the new media environment. Levy also explains, the new media enables a community member to gain access to a collective discussion, negotiation, and development (Jenkins, 2006). The BTS-Army community administrator in Surabaya states that the community acts as a discussion forum for the members, particularly those struggling with their life problems. The administrator declares that the community members try to be there for each other and to provide solutions. They say that one of BTS's message is to encourage the fans to find their happiness.

Overall, BTS-Army acts as social agents who promote social awareness globally and locally, mainly through the Love Yourself campaign. BTS's active promotion of social awareness influences the BTS-Army as they take that as part of their fandom identity as they become social agents. The BTS-Army community in Surabaya acts as social agents when they engage in various social activities to promote social awareness values. Several examples are East Java Cares Tsunami Banten (donations for Banten tsunami victims), K-Charity (donations every year for disadvantaged people), "Army Times To Charity" \#SaveRiau \#SaveKalimantan (donation for victims of the Riau disaster), a blood donor event in collaboration with PMI (Indonesian Red Cross), 
caring for cancer patients, sharing 'takjil' (sweet food eaten upon breaking the fast) during Ramadan, and "breaking the fast" events with orphans.

We have open donations for earthquake victims in Lombok, for fire victims in Kalimantan, in cooperation with PMI (Indonesian Red Cross Society). All done in the name BTS-Army. Yes, because the donated contributions came from the Army. We want the Army who take part in this donation to feel valued. Besides, they can also think that being an Army is useful. [SAND, interview on March 8, 2020].

The fans conduct various charity events under the BTS-Army community name. The names incorporate a sense of cultural identity as the fans of a K-Pop idol group that promotes social awareness. One member of the BTS-Army community in Surabaya states they feel proud to assume the identity because it gives them purpose. They think that they contribute to society.

\section{Conclusion}

The advancement of ICT in the digital age enables global fandom to be more active in interacting with both their idol group and with each other (i.e., to stay connected). A construction of fandom identity influence how fandom act as social agents. As the fandom adopts the idol groups' value, they act as passive recipients, but they also produce their fan cultural identity. The BTS-Army community in Surabaya shows how the local fandom community focuses on the positive messages against the social prejudice over fandom. When they act as social agents, as an extension of the Love Yourself campaign at the local level, they promote BTS's positive image as an idol group that promotes social awareness among the youth.

The Surabaya community's case is just one example of how the BTS-Army contributes to the spread of idol groups' positive images. This case us an example of how fandom influences idol's popularity. The case of BTS-Army shows that when the idol group has a clear vision over their identity, it contributes to the fan cultural identity and how they act as social agents. In return, this goes back to the idol group itself when it leads to their increasing popularity. The new media here act as a crucial medium that enables these virtual interactions.

\section{Acknowledgments}

We would like to give out appreciate to LPPM Universitas Pembangunan Nasional (UPN) Veteran Jawa Timur, and BTS-Army Surabaya Community.

\section{Conflicts of interest}

Author declares no conflict of interest.

\section{References}

Achmad., Z. A. (2019). Integrasi Program Dakwah dan Budaya: Studi Etnografi Virtual Mediamorfosis Radio Nada FM Sumenep Madura. Jurnal Komunikasi Islam, 9(2), 238-263. https:/ / doi.org/10.15642/jki.2019.9.2.238-263

Achmad, Z. A., \& Ida, R. (2018). Etnografi Virtual Sebagai Teknik Pengumpulan Data Dan Metode Penelitian. The Journal of Society $\mathcal{E}$ Media, 2(2), 130. 
https:/ / doi.org/10.26740/jsm.v2n2.p130-145

Achmad, Z. A., \& Ida, R. (2019). The Shifting Role of The Listeners in the Mediamorphosis Process of Culture Radio: A Case Study of Jodhipati 106,1 FM. Masyarakat, Kebudayaan Dan Politik, 32(3), 240-250.

Aditia, A. (2019). BTS Sebut Army Indonesia Terbesar di Asia. Entertainment.Kompas.Com.

https:/ / entertainment.kompas.com/read/2019/10/16/170614010/bts-sebutarmy-indonesia-terbesar-di-asia

Ardia, V. (2014). Drama korea dan Budaya Popular. Jurnal Komunikasi, 2(3), 12-18.

Big Hit Entertaiment. (2020). Discography: BTS. Ibighit.Com. https://ibighit.com/bts/eng/discography/

Blake, E. (2018). The Strength Of K-Pop Fandom, By The Number. Forbes.Com. https:/ / www.forbes.com/sites/emilyblake1/2018/04/04/k-popnumbers/\#2bb1cc9c48ab

Boellstorff, T., Nardi, B., Pearce, C., \& Taylor, T. . (2003). Ethnography and Virtual Worlds: A Handbook of Method (Issue 1). Princeton University Press. https:/ / doi.org/10.16309/j.cnki.issn.1007-1776.2003.03.004

Bok-rae, K. (2015). Past, Present and Future of Hallyu (Korean Wave). American International Journal of Contemporary Research, 5(5), 154-160. http://www.aijcrnet.com/journals/Vol_5_No_5_October_2015/19.pdf

Booth, P. (2018). A Companion to Media Fandom and Fan Studies. A Companion to Media Fandom and Fan Studies, 1-563. https:/ / doi.org/10.1002/9781119237211

Chang, Y. (2014). Research on the Identity Construction of Korean Pop Music ' s Fandom Groups on the Weibo Platform, Exemplified by G-Dragon ( Kwon JiYong ) [Uppsala Universitet]. In Thesis of Department of Informatics and Media Master Program in Digital Media $\mathcal{E}$ Society Uppsala University. https://doi.org/10.5194/acp-9-4039-2009

Duffett, M. (2013). Undestanding Fandom: An Introduction To The Study of Media Fan Culture (Issue 1). Bloomsbury. https://doi.org/10.16309/j.cnki.issn.10071776.2003.03.004

Hills, M. (2002). Fan Cultures (Studies in Culture and Communication). In Fan Cultures. Routledge.

Hine, C. (2000). Virtual ethnography. In Virtual Ethnography. Sage Publications. https:/ / doi.org/10.4324/9781315797915-4

Ida, R. (2008). Consuming Taiwanese Boys Culture: Watching Meteor Garden with Urban Kampung Women in Indonesia. In A. Heryanto (Ed.), Popular Culture in Indonesia: Fluid Identities in Post-Authoritarian Politics (pp. 93-110). Routledge. http://www.magisterseniusu.com/uploads/1/8/0/0/1800340/_media_culture _and_social_change_in_asia_series_ariel_heryantopopular_culture_in_indonesia_fluid_identities_in_post-authoritarian_politics_routledge_2008_.pdf

Jang, W., \& Song, J. E. (2017). The Influences of K-pop Fandom on Increasing Cultural Contact. Community Sociology, 18(2). https://barnettcenter.osu.edu/sites/default/files/2019-08/the_influences_of_kpop_fandom.pdf

Jenkins, H. (1992). Textual Poachers: Television Fans \& Participatory Culture. Routledge.

Jenkins, H. (2006). Fans, Bloggers, and Gamers: Exploring Participatory Culture. New York University Press.

Jin, D. Y. (2018). An Analysis of the Korean Wave as Transnational Popular Culture: North American Youth Engage Through Social Media as TV Becomes Obsolete. 
International Journal of Communication, 12, 404-422.

Kumbara, A. A. N. A., Dewi, A. . S. K., Liando, M. R., \& Wiasti, M. (2020). Cultural Disruption and Challenges for Anthropology in the Development of Multicultural Communities. ETNOSIA: Jurnal Etnografi Indonesia, 5(1), 10. https://doi.org/10.31947/etnosia.v5i1.8679

Lamerichs, N. (2018). Productive Fandom: Intermediality and Affective Reception in Fan Cultures. Amsterdam University Press. https://doi.org/10.2307/j.ctv65svxz.15

Samovar, L. A., Porter, R. E., \& McDaniel, E. R. (2010). Komunikasi Lintas Budaya: Communication Between Cultures. Salemba Humanika.

Sugihartati, R. (2017). Budaya Populer dan Subkultur Anak Muda: Antara Resistensi dan Hegemoni Kapitalisme di Era Digital. Airlangga University Press.

Tokopedia. (2019). Fakta Unik BTS ARMY, Fandom Terbesar di Dunia K-Pop. Tokopedia.Com. https://www.tokopedia.com/blog/profil-bts-army/

Wylie, H. (2019). BTS and UNICEF Call On Young People to Spread Kindness on International Day of Friendship: Global Pop Group Releases Video to Call for An End to Violence in and Around Schools. Unicef.Org. https://www.unicef.org/pressreleases/bts-and-unicef-call-young-people-spread-kindness-international-dayfriendship 